\title{
Nematode assemblages of deep-sea and shelf break sites in the North Atlantic and Mediterranean Sea
}

\author{
Karline Soetaert*, Carlo Heip \\ Netherlands Institute of Ecology, Centre for Estuarine and Coastal Research, Vierstraat 28, NL-4401 EA Yerseke, \\ The Netherlands
}

\begin{abstract}
The nematode community structure of several shelf break and deep-sea stations in the North Atlantic and the Mediterranean is compared using data from the literature. Samples from 2 Mediterranean deep-sea canyons have a unique fauna of predatory and scavenging nematodes (e.g. Synonchiella, Halichoanolaimus, Gammanemal which comprise some 20 to $30 \%$ of the community, while some of the typical deep-sea genera (Theristus, Acantholaimus) are only marginally present. The nematode generic composition of the other sites reveals a gentle transition from the shelf break (Bay of Biscay; Mediterranean) over the slope (Mediterranean) towards the continental rise, abyssal plain and hadal depths (Bay of Biscay, Puerto Rico Trench, HEBBLE site, Hatteras Abyssal Plain). At all these sites predators and omnivores are less abundant $(<10 \%)$, while bacterial feeders (deposit and epistrate feeders) predominate. With increasing water depth, the genus Sabatieria becomes less dominant, while the genera Theristus, Acantholaimus and Halalaimus gain in importance. We suggest that this is caused by the growing importance of the oxic mineralization pathway at greater depth. As such the relative amount of organic matter that enters the suboxic and anoxic regions of the sediment diminishes with depth. These anoxic or suboxic regions are typically inhabited by Sabatieria. It is argued that larger fluxes of organic matter to the bottom in the Mediterranean canyon, compared to the other sites, allow for a higher trophic complexity of the nematode communities and a higher mean nematode biomass. Trends in nematode biomass, mean individual weight and nematode density are discussed.
\end{abstract}

KEY WORDS: Deep-sea $\cdot$ Shelf $\cdot$ Nematode $\cdot$ Atlantic $\cdot$ Mediterranean

\section{INTRODUCTION}

In deep-sea sediments, the meiobenthos (40 to 1000 $\mu \mathrm{m}$ ) has a biomass equivalent to that of the larger infaunal animals (Tietjen 1992). The general patterns of abundance and biomass of the metazoan meiobenthos as a whole are well documented (see Thiel 1983, Tietjen 1992, Vincx et al. 1994 for a review), but its functional role in deep-sea food chains remains uncertain.

Nematodes are generally the most abundant metazoan component of the deep-sea meiobenthos and, compared to larger size classes, their numerical dominance frequently increases with water depth (Thiel 1975, Vincx et al. 1994). As their feeding ecology can be inferred from the morphology of their mouth cavity (Wieser 1953, Jensen 1987), nematodes offer unique opportunities to examine the trophic status of the deep-sea meiobenthos. However, studies that encom-

•E-mail: soetart@nioo.nl pass a description of the deep-sea nematode taxonomic composition are rare and limited to a few sites, i.e. the Mediterranean (Vitiello 1976, Vivier 1978, Soetaert et al. in press a), the Bay of Biscay (Dinet \& Vivier 1979), the deep-sea area from off North Carolina to the Venezuela Basin (Tietjen 1971, 1976, 1984, 1989), the Scotian Rise (Thistle \& Sherman 1985) and the Norwegian deep sea (Jensen 1988, Jensen et al. 1992). Rutgers van der Loeff \& Lavaleye (1986) described the nematode fauna of a northeast Atlantic site in terms of their trophic composition. Vanreusel et al. (1992) provided information on the nematode assemblages of the shelf break area in the Bay of Biscay.

Several authors have demonstrated that there is little overlap of nematode species composition, even between adjacent sites (Jensen 1988, Tietjen 1989), but that nematode generic distribution across different deep-sea environments is more uniform (Thistle \& Sherman 1985). Up until now the nematode assemblages of the investigated deep-sea sites have not been 
Table 1. List of sampling sites, measured variables, and literature references of the different stations used in this study. F: carbon flux; S: sediment characteristics; C: sediment carbon content; $N$ : nematode density; NC: nematode carbon content; NS: nematode species composition, NF: nematode feeding types

\begin{tabular}{|c|c|c|c|c|c|c|}
\hline Site & Variable & Reference & Area & $\begin{array}{l}\text { No. of } \\
\text { stations }\end{array}$ & Location & $\begin{array}{l}\text { Depth } \\
\text { range }(\mathrm{m})\end{array}$ \\
\hline \multicolumn{7}{|c|}{ Mediterranean - canyon } \\
\hline & S, NS & Vitiello (1976) & $\begin{array}{l}\text { Canyon du Planier/ } \\
\text { Cassidaigne }\end{array}$ & 10 & $43.0-43.1^{\circ} \mathrm{N}, 5.0-5.3^{\circ} \mathrm{E}$ & $310-650$ \\
\hline & $\begin{array}{l}\mathrm{C}, \mathrm{S}, \mathrm{N} \\
\mathrm{NC}\end{array}$ & $\begin{array}{l}\text { deBovée et al. (1990) } \\
\text { deBovée \& Labat (1993) }\end{array}$ & Gulf of Lions canyons & 16 & $42.3-42.6^{\circ} \mathrm{N}, 3.3-5.1^{\circ} \mathrm{E}$ & $672-1720$ \\
\hline & $\mathrm{F}$ & Buscail et al. $(1990)$ & Lacaze-Duthiers & 1 & $42.3^{\circ} \mathrm{N}, 3.3 \mathrm{E}$ & 650 \\
\hline & N, S & Soetaert et al. (1991a) & Off Corsica & 4 & $42.4^{\circ} \mathrm{N}, 8.4^{\circ} \mathrm{E}$ & $142-370$ \\
\hline & NC & Soetaert et al. (unpubl.) & Off Corsica & 4 & $42.4^{\circ} \mathrm{N}, 8.4^{\circ} \mathrm{E}$ & 370 \\
\hline \multicolumn{7}{|c|}{ Mediterranean - slope/shelf break } \\
\hline & $\mathrm{C}$ & Soetaert et al. (unpubl.) & Off Corsica & 10 & $42.4^{\circ} \mathrm{N}, 8.3-8.4^{\circ} \mathrm{E}$ & $160-1220$ \\
\hline & NS & Soetaert et al. (in press a) & & & & \\
\hline & $\mathrm{N}, \mathrm{S}$ & Soetaert et al. (1991a) & & & & \\
\hline & $\mathrm{NC}$ & Soetaert \& Heip (1989) & & & & \\
\hline & $\mathrm{N}, \mathrm{S}, \mathrm{C}$ & deBovée et al. (1990) & Gulf of Lions & 13 & $41.5-42.5^{\circ} \mathrm{N}, 4.5-5.1^{\circ} \mathrm{E}$ & $1750-2367$ \\
\hline \multicolumn{7}{|c|}{ Bay of Biscay - shelf break } \\
\hline & $\mathrm{N}, \mathrm{NS}, \mathrm{S}$ & Vanreusel et al. (1992) & Off La Coruna & 2 & $43.5-43.6^{\circ} \mathrm{N}, 8.3^{\circ} \mathrm{W}$ & $190-325$ \\
\hline & $N$ & Vincx et al. (1994) & & 4 & $44.0-44.9^{\circ} \mathrm{N}, 0.1-1.0 \mathrm{~W}$ & $123-300$ \\
\hline \multicolumn{7}{|c|}{ Bay of Biscay - continental rise/abyssal } \\
\hline & $N S, C, S$ & Dinet \& Vivier (1979) & BIOGAS area & 5 & $44.1-47.4^{\circ} \mathrm{N}, 4.1-10.2^{\circ} \mathrm{W}$ & $2090-4725$ \\
\hline & $\mathrm{S}$ & Auffret (1985) & & & & \\
\hline & $\mathrm{N}$ & Dinet \& Vivier (1977) & & & & \\
\hline & $\mathrm{NC}$ & Dinet et al. (1985) & & & & \\
\hline & $F$ & Khripounoff et al. (1985) & & & & \\
\hline \multicolumn{7}{|c|}{ NE Atlantic dumpsite - abyssal plain } \\
\hline & $N F, N, N C$ & R. v d Loeff \& Lavaleye (1986) & Iberian deep sea & 15 & $41.0-47.0^{\circ} \mathrm{N}, 14.6-17.2^{\circ} \mathrm{W}$ & $3958-4800$ \\
\hline \multicolumn{7}{|c|}{ NE Atlantic slope - abyssal } \\
\hline & $\mathrm{N}$ & Vincx et al. (1994) & BIOtrans area & 2 & $48.6^{\circ} \mathrm{N}, 16.4^{\circ} \mathrm{W}$ & 4560 \\
\hline & $\mathrm{N}$ & Vincx et al. (1994) & Eumeli - off Mauretania & 23 & $18.4-21.4^{\circ} \mathrm{N}, 9.5-31.1^{\circ} \mathrm{W}$ & $1543-4652$ \\
\hline & $N$ & Vincx et al. (1994) & Madeira Abyssal Plain & 2 & $32.7^{\circ} \mathrm{N}, 15.1^{\circ} \mathrm{W}$ & $4856-5120$ \\
\hline & $N$ & Vincx et al. (1994 & $\begin{array}{l}\text { Porcupine Seabight/ } \\
\text { Porcupine Abyssal Plain }\end{array}$ & 6 & $50.0-52.6^{\circ} \mathrm{N}, 8.2-10.8^{\circ} \mathrm{W}$ & $398-4850$ \\
\hline & $N$ & Pfannkuche (1985) & Porcupine Seabight & 11 & $49.3-52.2^{\circ} \mathrm{N}, 13.0-14.2^{\circ} \mathrm{W}$ & $500-4850$ \\
\hline & $N$ & Thiel (1972) & Iberic Sea & 6 & $42.1-42.6^{\circ} \mathrm{N}, 14.0-14.6^{\circ} \mathrm{W}$ & $5272-5340$ \\
\hline \multicolumn{7}{|c|}{ Norwegian sea-Vöring Plateau } \\
\hline & $\mathrm{N}, \mathrm{NC}, \mathrm{C}$ & Jensen et al. (1992) & Vöring plateau & 7 & $67.4-67.5^{\circ} \mathrm{N}, 5.5-6.0^{\circ} \mathrm{E}$ & $1245-1424$ \\
\hline \multicolumn{7}{|c|}{ HEBBLE - continental rise } \\
\hline & NS, S & Thistle \& Sherman (1985) & Scotian rise & $1^{b}$ & $40.2^{\circ} \mathrm{N}, 63.1^{\circ} \mathrm{W}$ & 4626 \\
\hline & $N_{1} \mathrm{C}$ & Thistle et al. (1985) & & & & \\
\hline & $\mathrm{F}$ & Gardner \& Richardson (1992) & & & & \\
\hline \multicolumn{7}{|c|}{ Hatteras Abyssal Plain } \\
\hline & NS, S, C & Tietjen (1989) & Off North Carolina & 1 & $32.3^{\circ} \mathrm{N}, 70.2^{\circ} \mathrm{W}$ & 5411 \\
\hline & $\mathrm{N}, \mathrm{F}$ & Tietjen et al. (1989 & & & & \\
\hline \multicolumn{7}{|c|}{ Puerto Rico Trench } \\
\hline & $\mathrm{NS}, \mathrm{S}, \mathrm{C}$ & Tietjen (1989) & Off Hispaniola & 4 & $18.5-19.4^{\circ} \mathrm{N}, 66.1^{\circ} \mathrm{W}$ & $2217-8380$ \\
\hline & $N, F$ & Tietjen et al. (1989) & & & & \\
\hline \multicolumn{7}{|c|}{$\begin{array}{l}{ }^{d} \text { Using proposed regression equations for nematode biomass and density } \\
\text { bean of } 2 \text { stations }\end{array}$} \\
\hline
\end{tabular}


consistently compared and it has not been examined how they relate to assemblages at the shelf break.

In this paper we use published data on nematode density, biomass and generic composition and examine whether patterns in nematode assemblage composition can be discerned across several deep-sea and shelf break sites. Trends in nematode diversity at different deep-sea sites were already investigated by Soetaert et al. (1991b).

\section{MATERIAL AND METHODS}

A list of sampling sites and abiotic and biotic variables used in this study is given in Table 1 . A conversion of nematode dry weight to carbon was performed using a conversion of $0.5 \mathrm{~g} \mathrm{C}(\mathrm{g} \mathrm{DW})^{-1}$, nematode dry weight was assumed to be $25 \%$ of nematode wet weight.

The analysis of the nematode taxonomic composition was based on relative abundances of the most abundant genera (defined as having a dominance higher than $1 \%$ ). A maximum of $20 \%$ of all individuals was thus excluded from the analysis. As there can be some confusion between the related genera Spiliphera and Acantholaimus (Gerlach et al. 1979, Thistle \& Sherman 1985, Vivier 1985), they were combined for the present study. Similarly, the genera Monhystera, Monhystrella,
'Monhysteridae gen.', 'Monhysterina gen.' or 'Monhysterida' were combined as 'Monhysteridae'.

Nematode community composition was analyzed by means of the classification technique TWINSPAN (TWo-way INdicator SPecies ANalysis; Hill 1979a). This technique provides clusters of stations with similar generic composition. For the current analysis, no 'pseudospecies cut levels' were defined, i.e. stations were discriminated by generic dominances larger or smaller than $1 \%$. Ordination of the nematode generic data was done using detrended correspondence analysis (DCA; Hill 1979b). By means of this technique the complex multivariate structure of the data can be represented in 2-dimensional graphs in which related entities are close, whereas dissimilar entities are far away from one another. Both stations and species can be represented in ordination graphs and the position of the station is a weighted average of the species positions. In the resulting DCA plot only the most abundant genera (total abundance) are represented.

\section{RESULTS}

\section{Abiotic characteristics}

Positions and abiotic characteristics of the sampling stations are represented in Fig. 1.

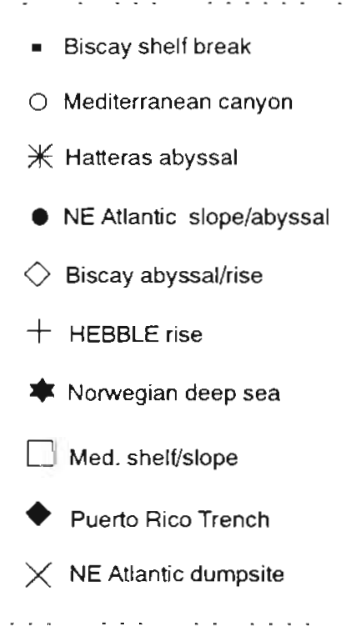

Fig. 1. (a) Position and (b to d) abiotic characteristics versus depth of the different stations. For a list of references, see Table 1
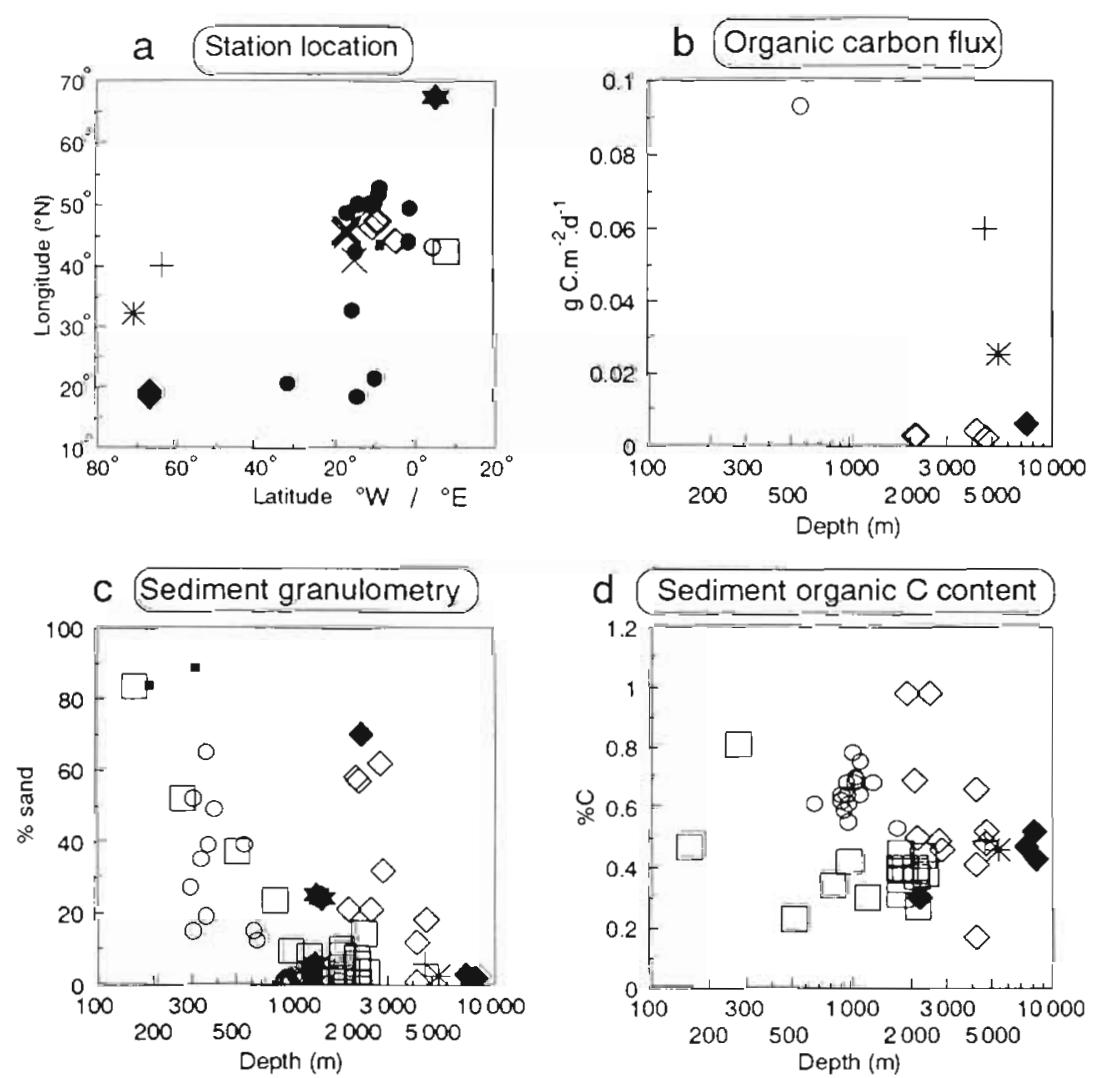
Stations are located either at the east side of the North Atlantic (Bay of Biscay, NE Atlantic dumpsite, Norwegian deep sea, NE Atlantic slope abyssal), in the Mediterranean or in the western North Atlantic (Puerto Rico Trench, Hatteras Abyssal Plain, HEBBLE site).

The organic carbon flux was measured with sediment traps for a Mediterranean canyon [Buscail et al. 1990, $45 \mathrm{~m}$ above the bottom (mab)], for 3 stations in the deep Bay of Biscay (Khripounoff et al. 1985; 200 mab), for the Hatteras Abyssal Plain and Puerto Rico Trench (Tietjen et al. 1989; $10 \mathrm{mab}$ ) and for the HEBBLE site (Gardner \& Richardson 1992; 100/ 500 mab). Estimates of organic flux at the HEBBLE site varied from 0.004 to $0.06 \mathrm{~g} \mathrm{C} \mathrm{m}^{-2} \mathrm{~d}^{-1}$, depending on whether the trap was situated in the benthic boundary layer (and hence also registered resuspension flux) or not. Similarly at Hatteras Abyssal Plain, flux estimates using traps 780 mab (Gardner \& Richardson 1992) were much lower than the ones reported in Tietjen et al. (1989). For consistency, only fluxes in the benthic boundary layer were used in this study.

The organic flux in the Mediterranean canyon was highest and, the HEBBLE site excluded, was at least 3 fold the flux of the other sites. The organic flux at the HEBBLE site was about twice as high as at Hatteras Abyssal Plain, where organic fluxes were 4 to 10 times higher than in the Bay of Biscay Abyssal Plain and the Puerto Rico Trench.

Sediment types varied from coarse sands to pure muds. On average the stations located on the shelf break were more sandy than those on the slope which in turn had coarser sediments than deeper stations.
Some of the deep stations (Bay of Biscay, Puerto Rico Trench) were very sandy. Particulate organic carbon content generally was between 0.2 and $1 \%$ of the total sediment weight. There was no relationship between $\% \mathrm{C}$ and depth.

\section{Nematode density and weight characteristics}

Nematode density, individual $\mathrm{C}$ weight and total biomass are represented in Fig. 2. Some of the studies only provide nematode densities, others also give mean nematode weights or total nematode biomasses. Nematode densities were highest (up to $2.5 \times 10^{6}$ ind. $\mathrm{m}^{-2}$ ) along the North East Atlantic slope, less than $1000 \mathrm{~m}$ deep (Pfannkuche 1985) and in a Mediterranean canyon at depths less than $400 \mathrm{~m}$ (Soetaert et al. 1991a). At the deeper sites, the number of nematodes generally did not exceed $10^{6}$ ind. $\mathrm{m}^{-2}$.

Mean nematode carbon content varied from less than $0.01 \mu \mathrm{g} \mathrm{C}$ ind.$^{-1}$ at some North Atlantic sites (Rutgers van der Loeff \& Lavaleye 1986) to about $0.4 \mu \mathrm{g} \mathrm{C}$ ind $^{-1}$ at one Norwegian deep-sea site (Jensen et al. 1992). Mean nematode weight on the Mediterranean slope and shelf (Soetaert \& Heip 1989) was lower than at comparable depths along the shelf break in the Bay of Biscay (Vanreusel et al. 1992), in a Mediterranean canyon (deBovée \& Labat 1993, K. Soetaert unpubl.) or in the Norwegian Sea (Jensen et al. 1992).

Total nematode biomass spanned 2 orders of magnitude and varied from $0.002 \mathrm{~g} \mathrm{C} \mathrm{m}^{-2}$ at a station in the Puerto Rico Trench (>7000 m deep; Tietjen et al. 1989)
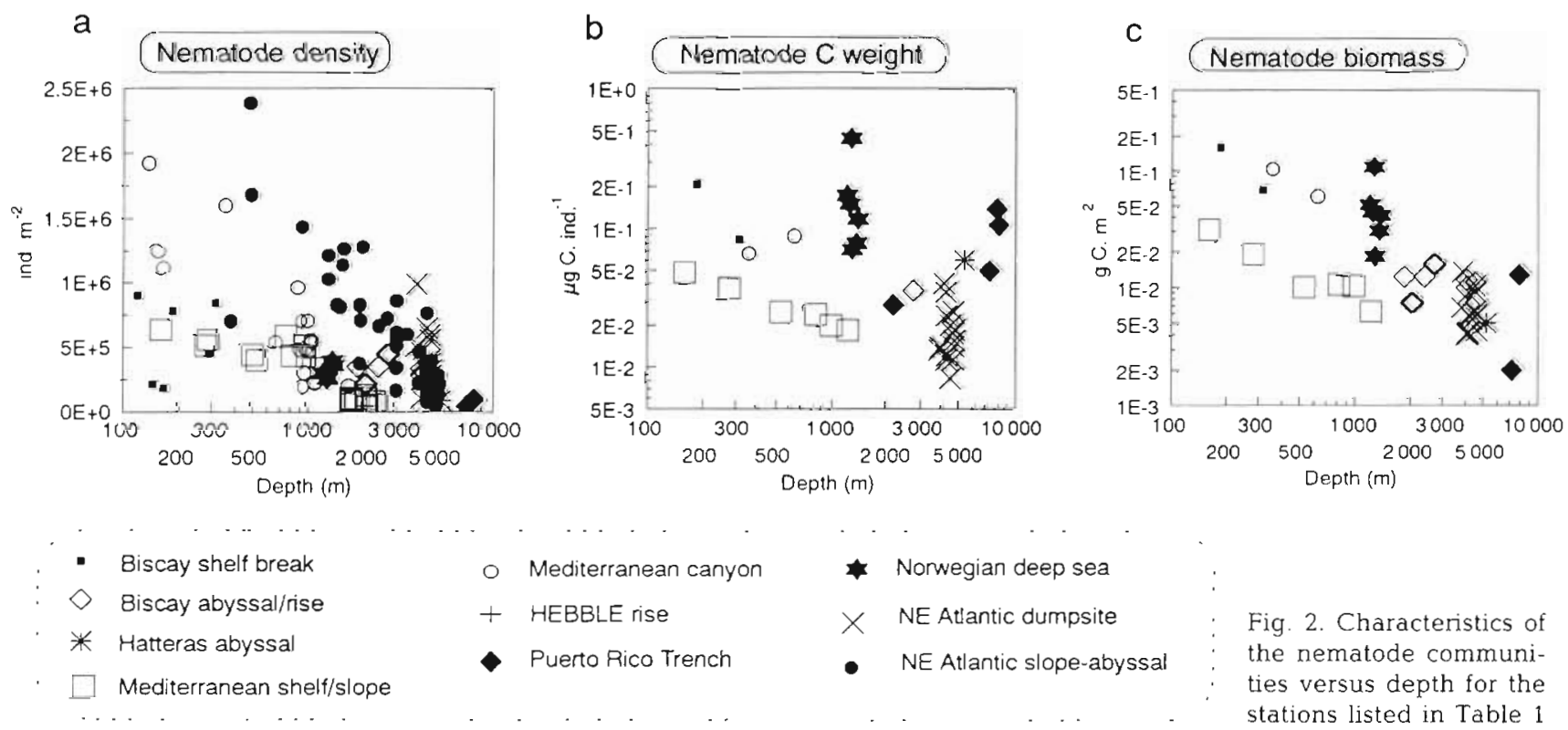

O Mediterranean canyon

+ HEBBLE rise

- Puerto Rico Trench
Norwegian deep sea

X NE Atlantic dumpsite

- NE Atlantic slope-abyssal
Fig. 2. Characteristics of the nematode communities versus depth for the stations listed in Table 1 
to more than $0.15 \mathrm{~g} \mathrm{C} \mathrm{m}^{-2}$ at shelf-break stations in the Bay of Biscay (Vanreusel et al. 1992). Nematode biomass at deeper stations ( $>1500 \mathrm{~m}$ ) was less than $0.02 \mathrm{~g} \mathrm{C} \mathrm{m}^{-2}$.

\section{Nematode generic composition}

The analysis of nematode generic composition was based on data from the Mediterranean (Vitiello 1976 , Soetaert et al. in press a), the Bay of Biscay (Dinet \& Vivier 1979, Vanreusel et al. 1992), the HEBBLE site (Thistle \& Sherman 1985), the Hatteras Abyssal Plain and the Puerto Rico Trench (Tietjen 1989).

A total of 163 genera belonging to 35 families were included in the analysis. The resulting dendrogram of the TWINSPAN analysis is represented in Fig. 3. All the stations located in the Mediterranean canyon were separated first by this method. From the remaining group, the stations located at the Mediterranean continental slope and shelf break and stations at the shelf break of the Bay of Biscay formed one cluster, the continental rise, abyssal and hadal stations formed another cluster. The plot resulting from the DCA ordination (first 2 axes) is represented in Fig. 4 . The species and stations in the DCA graph are situated along 2 main axes, one discriminates species or stations from the Mediterranean canyon from the other sites, while the second axis relates to station depth: stations are ordered from the shelf break, over the slope to the con-

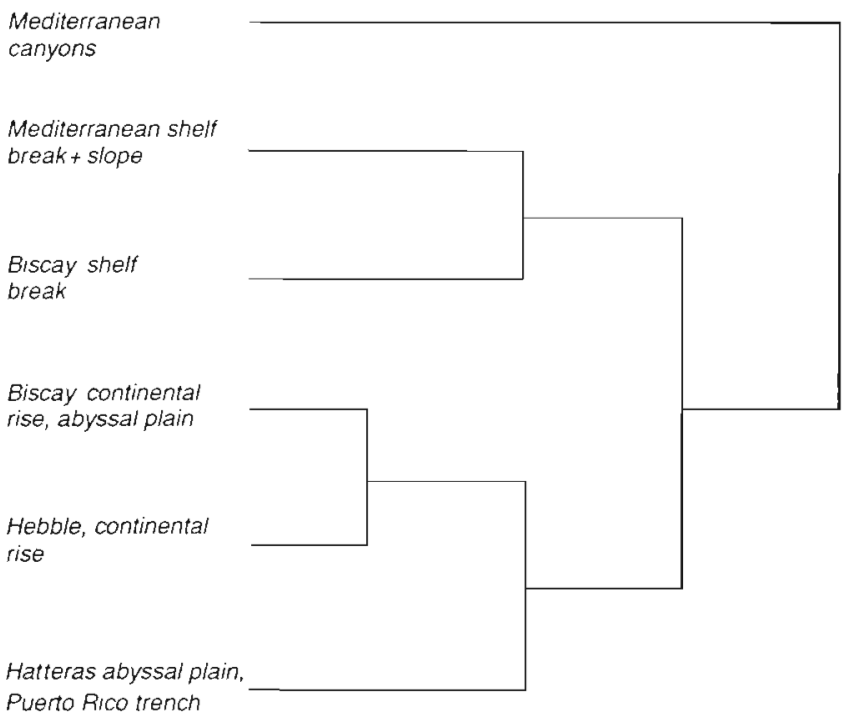

Fig. 3. TWINSPAN dendrogram indicating the main TWINSPAN divisions

tinental rise, abyssal and hadal depths. The mean dominance of the 20 most abundant genera in the canyons, the shelf-break stations, the slope stations and the continental rise to hadal stations are also listed in Table 2.

The genus Sabatieria is most dominant in the Mediterranean canyon, on the slope and in the shelf stations. It is much less prominent in the deeper stations.

Table 2. List of the most abundant genera at the different sites. Indicated are the mean $\%$ abundances at all stations. Numbers in parentheses refer to groups delineated on the DCA graph (Fig. 4a)

\begin{tabular}{|c|c|c|c|c|c|c|c|}
\hline Rise, abyssal, hadal & (1) & Slope & & Shelf break & & Canyon & \\
\hline Theristus & 21.6 & Sabatieria & 15.8 & Sabatieria & 9.3 & Sabatieria & 18.4 \\
\hline Acantholaimus ${ }^{a}$ & 14.3 & Monhysteridae & 11.2 & Daptonema & 6.5 & Sphaerolaimus & 4.1 \\
\hline Halalaimus & 8.0 & Acantholaimus ${ }^{\mathrm{a}}$ & 5.9 & Comesa & 6.4 & Synonchiella & 2.9 \\
\hline Monhysteridae & 6.2 & Amphimonhystrella & 4.1 & Richtersia & 5.8 & Cervonema & 2.6 \\
\hline Microlaimus & 5.4 & Halalaimus & 3.7 & Halalaimus & 4.5 & Siphonolaimus & 1.9 \\
\hline Desmoscolex & 3.3 & Richtersia & 3.6 & Pselionema & 2.7 & Halalaimus & 1.8 \\
\hline Syringolaimus & 2.3 & Tricoma & 3.1 & Desmodora & 2.6 & Longicyatholaimus & 1.8 \\
\hline Sphaerolaimus & 1.7 & Dichromadora & 3.0 & Prochromadorella & 2.5 & Halichoanolaimus & 1.6 \\
\hline Quadricoma & 1.6 & Desmoscolex & 3.0 & Actinonema & 2.4 & Thalassoalaimus & 1.4 \\
\hline Leptolaimus & 1.5 & Leptolaimus & 2.7 & Desmoscolecidae & 2.4 & Hopperia & 1.2 \\
\hline Cervonema & 1.4 & Molgolaimus & 2.6 & Minolaimus & 2.2 & Microlaimus & 1.0 \\
\hline Diplopeltula & 1.4 & Aegialoalaimus & 2.2 & Trichotheristus & 2.2 & Odontophora & 0.9 \\
\hline Campylaimus & 1.2 & Daptonema & 1.9 & Monhysteridae & 4.3 & Oxystomina & 0.9 \\
\hline Thalassoalaimus & 1.1 & Calomicrolaimus & 1.7 & Diplopeltula & 2.2 & Terschellingia & 0.9 \\
\hline Sabatieria & 1.0 & Oxystomina & 1.6 & Setosabatieria & 2.1 & Syringolaimus & 0.8 \\
\hline Actinonema & 0.9 & Syringolaimus & 1.5 & Calomicrolaimus & 1.7 & Gammanema & 0.7 \\
\hline Tricoma & 0.9 & Microlaimus & 1.4 & Bolbolaimus & 1.7 & Richtersia & 0.6 \\
\hline Amphimonhystera & 0.8 & Diplopeltoides & 1.1 & Tricoma & 1.5 & Mononcholaimus & 0.6 \\
\hline Oxystomina & 0.7 & Diplopeltula & 1.0 & Viscosia & 1.5 & Paramesacanthion & 0.6 \\
\hline Longicyatholaimus & 0.7 & Sphaerolaimus & 1.0 & Microlaimus & 1.3 & Paralinhomoeus & 0.6 \\
\hline
\end{tabular}


a D.C.A. - STATION PLOT

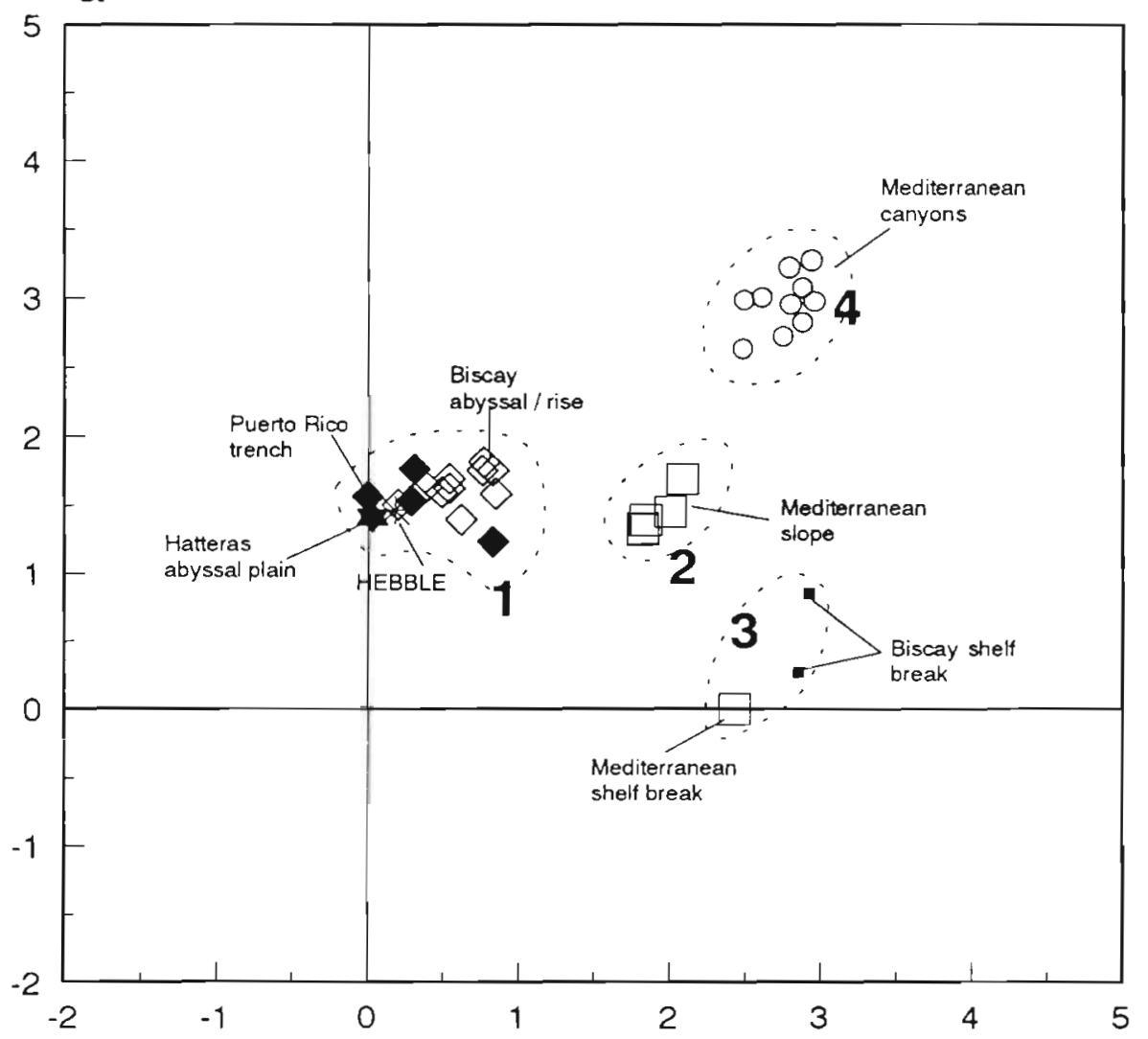

b D.C.A. - GENUS PLOT

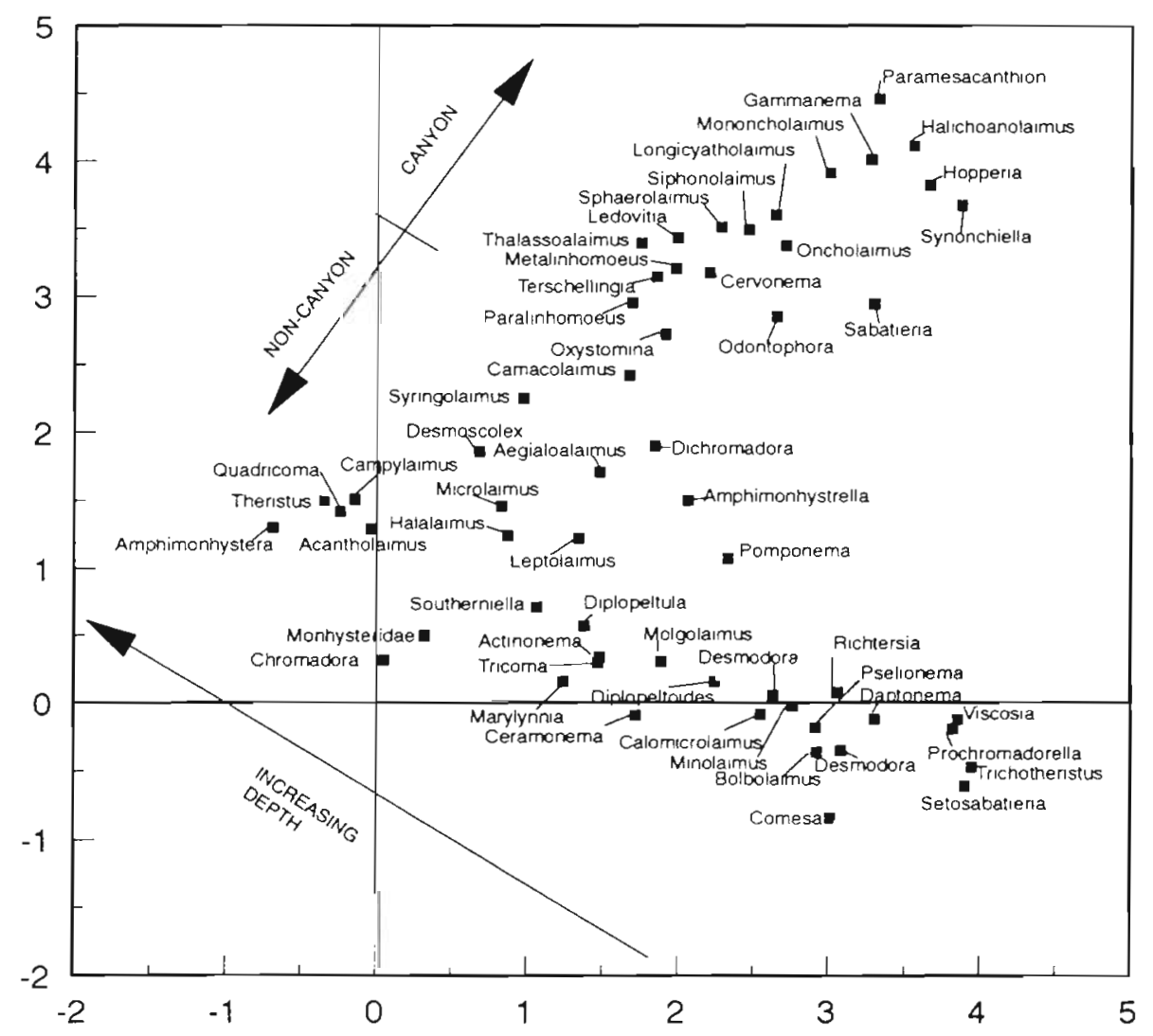

Fig. 4. DCA plots of (a) stations and (b) most abundant genera along the 2 principal ordination axes 
Dominant deep-sea genera are Theristus, Acantholaimus + Spiliphera, Halalaimus and genera belonging to the Monhysteridae. Mediterranean canyon sites are distinguished from the other stations by a number of large predatory nematodes, such as Synonchiella, Halichoanolaimus, Gammanema and Paramesacanthion or scavengers such as Mononcholaimus. The genus Sphaerolaimus, a predatory nematode which is abundant in the rise to hadal stations, ranks second in the Mediterranean canyon. Many nematodes that are typical for the Mediterranean slope (Acantholaimus + Spiliphera, Monhysteridae genera, Amphimonhystrella, Tricoma, Richtersia, Desmoscolex) are much less abundant or absent in the canyon, although the depth ranges overlap. The 3 shelf-break stations have high abundances of Sabatieria, Daptonema and Richtersia in common. The genus Comesa was very abundant on the Mediterranean shelf break exclusively.

A correspondence analysis (i.e. without detrending; not depicted) produced a similar result but, due to the presence of the genus Comesa in the Mediterranean, the station on the Mediterranean shelf was further separated from the shelf stations of the Bay of Biscay.

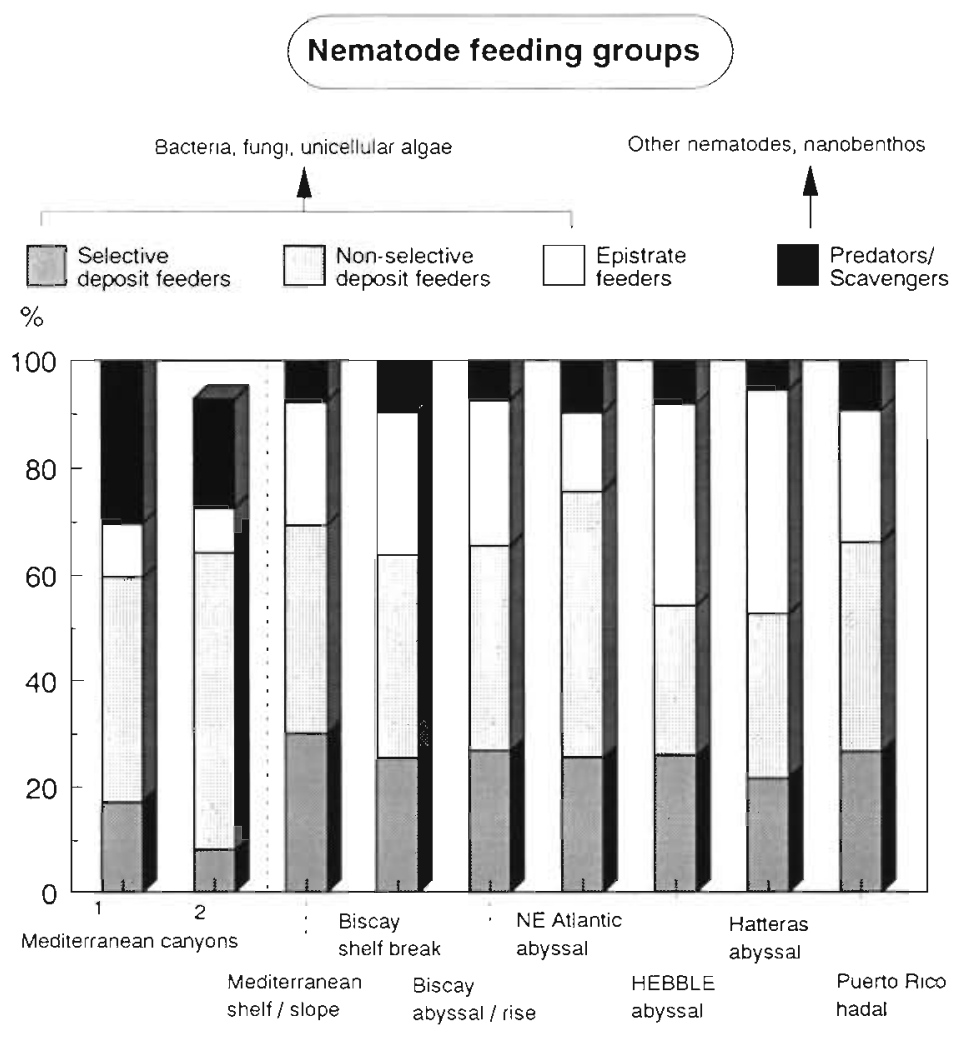

Fig. 5. Nematode feeding group composition of the different sites. (1) Based on data of Vitiello (1976), (2) data obtained from deBovée \& Labat (1993)

\section{Nematode feeding strategies}

According to Wieser (1953) nematode feeding behaviour can be inferred from buccal morphology. He distinguished between 'selective deposit feeders' (the so-called group 1A), characterized by small buccal cavities without teeth, the 'non-selective deposit feeders' (1B), having larger buccal cavities without teeth, the 'epistrate feeders' (2A) with small teeth and the 'omnivore predators' (2B) with large teeth. According to Jensen (1987) groups $1 \mathrm{~A}, 1 \mathrm{~B}$ and $2 \mathrm{~A}$ all feed on bacteria, fungi and unicellular algae, either by direct ingestion (the deposit feeders) or by sucking out the contents (epistrate feeders). Group 2B either catches living prey or has a scavenging life style.

At all sites the deposit feeders (whether with small or large buccal cavities) were most abundant (Fig. 5) and together they comprised 54 to $79 \%$ of the nematode community. In the non-canyon sites the 'epistrate' feeders (mainly Acantholaimus + Spiliphera in the deep sea) were the second most important group, while the predators + scavengers were relatively unimportant (usually less than $10 \%$ ). In the canyon, epistrate feeders and the non-selective deposit feeders were much less abundant, but the predatory or scav- enging nematodes comprised more than $20 \%$ of all nematodes, i.e. they were significantly more abundant than at the other sites (Fig. 6). deBovée \& Labat (1993) reported the presence of a mouthless species in the Mediterranean canyon which comprised $7.1 \%$ of the entire nematode assemblage

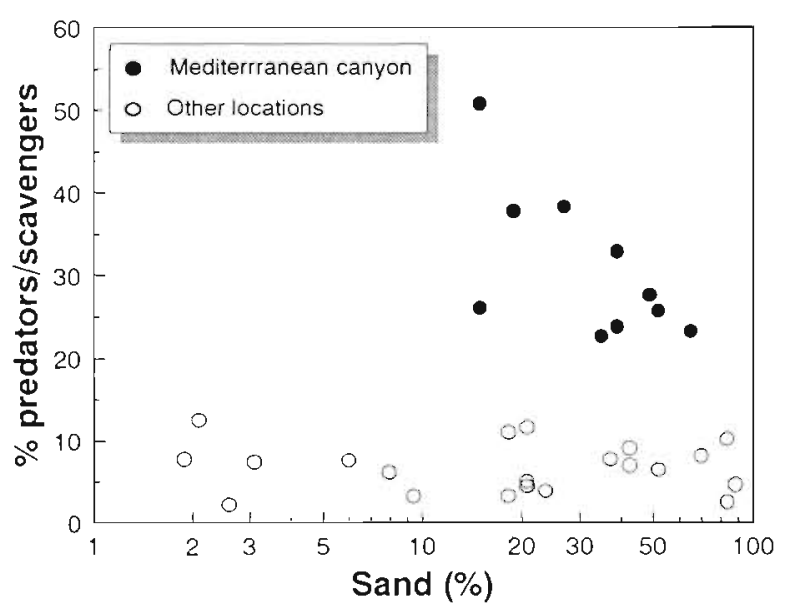

Fig. 6. Percent dominance of the predatory/omnivorous nematodes versus \% sand 


\section{DISCUSSION}

Examining data obtained from different researchers is not without risk, as methodological bias can interfere with real patterns. For instance, a multitude of sampling gear was used in the various studies, from small box corers (Soetaert et al. 1991a), larger box corers (Jensen 1988, Vanreusel et al. 1992) to multicorers (e.g. some of the data in Vincx et al. 1994) and their sampling efficiency is known to vary widely and unpredictably (Bett et al. 1994). Add to this the discrepancies inherent in further processing of the samples, the natural small-scale and temporal variability and it will be clear that a large degree of uncertainty is associated with the data.

Similarly, differences in specific or generic lists obtained from various researchers could be caused by taxonomic conflicts rather than reflecting real differences. For instance, the abundance of the genus Theristus in the deep sea, compared to the genus Daptonema on the shelf, may not be a real difference, as some authors consider the latter to be a subgenus of the former. Some nematode species are known to react to the seasonal deposition of phytodetritus in certain deep-sea areas (monhysterids and chromadorids in the BIOtrans area; Thiel et al. 1988/1989) and thus nematode assemblage structure may change during the course of the year. The samples used for our analysis were taken at different times of the year and differences observed could thus to some degree reflect seasonal changes. Nevertheless, the results we abtained seem robust and the different environments are discriminated by a multitude of genera.

\section{Taxonomic composition and trophic status}

There is a remarkable similarity in the generic composition of the various deeper stations (Fig. 7; rise/ abyssal). Although situated thousands of kilometres apart, and with depths varying from 2000 to as much as $8000 \mathrm{~m}$, the same genera were consistently observed. The most abundant ones were Theristus, Acantholaimus + Spiliphera and Halalaimus which on average comprised about $44 \%$ of the entire nematode community (in terms of density). The stations on the shelf break were characterized by other genera, i.e. Sabatieria, Daptonema, Comesa (the latter on the Mediterranean shelf break exclusively) and Richtersia, while the genus Halalaimus was also reasonably abundant. However, this transition zone from shelf to continental slope is not well studied, and only 3 stations were included in our analysis. It is likely that nematode generic composition is more variable in this region compared to the deeper sites. The taxonomic composi- tion of stations on the Mediterranean continental slope was somewhat in between the shelf break and the deeper (rise to hadal) stations, with Sabatieria, Acantholaimus + Spiliphera, Monhysteridae genera, Amphimonhystrella, Halalaimus and Richtersia as the dominant genera. The majority of nematode individuals (more than 90\%) in these 3 environments (shelf break, slope, rise/abyssal) had only small or no teeth which suggests that they feed on bacteria, fungi or unicellular algae (Jensen 1987, 1988), either through direct swallowing (deposit feeders) or by sucking out the cell content (epistrate feeders). Many of these bacterial-feeding nematodes are known to secrete mucus which acts as a trap for organic matter. This provides a unique substrate for microbial growth, and the bacteria are grazed upon (Riemann \& Schrage 1978, Jensen 1987). In the Mediterranean slope samples for instance (own observation), many nematodes were either completely or partly covered with bacteria, which were trapped in some kind of (mucus?) sheet that apparently resisted the various elutriation techniques (e.g. see descriptions of Desmoscolex variabilis in Soetaert 1989 or of Tricoma vincxae in Soetaert \& Decraemer 1989). Probably these bacterial envelopes are reminiscents of 'microbial gardens'. Similarly, Renaud-Mornant \& Gourbault (1990) reported gardening activities in some Monhysteridae from the Clarion-Clipperton fracture zone in the deep eastern central Pacific. Less than 10\% of the nematode individuals in the non-canyon sites were predators, while scavenging nematodes were only marginally present. Similar observations on the nematode feeding status were reported from the Venezuela Basin by Tietjen (1984), from the deep Norwegian Sea by Jensen (1988) and from the central eastern Pacific by Renaud-Mornant \& Gourbault (1990). The low density of scavengers was attributed to a lack of freshly dead organisms (Jensen 1988): biomass in the deep sea is low and most species are long-lived. Moreover, the more mobile epibenthic scavengers (Isaacs \& Schwartzlose 1975) are better adapted to forage on the occasional large food falls.

The most abundant genus in the Mediterranean canyons was Sabatieria, similar to the shelf break and slope stations, but there were some striking differences. More than $20 \%$ of all nematodes in the canyons were predators, while, compared to the other sites, there were fewer epistrate and deposit (i.e. bacterial) feeders (Figs. 6 \& 7). Thus the Mediterranean canyons support a trophically more complex nematode community (more abundant higher trophic levels) than the other sites. The Mediterranean canyons included in this study (Vitiello 1976, deBovée \& Labat 1993) are situated in the Gulf of Lions, an area of relatively high primary production (Cruzado \& Velasquez 1990) and act as natural traps (rather than conduits) of matter 


\section{Nematode communities from the shelf break to the abyssal depths}

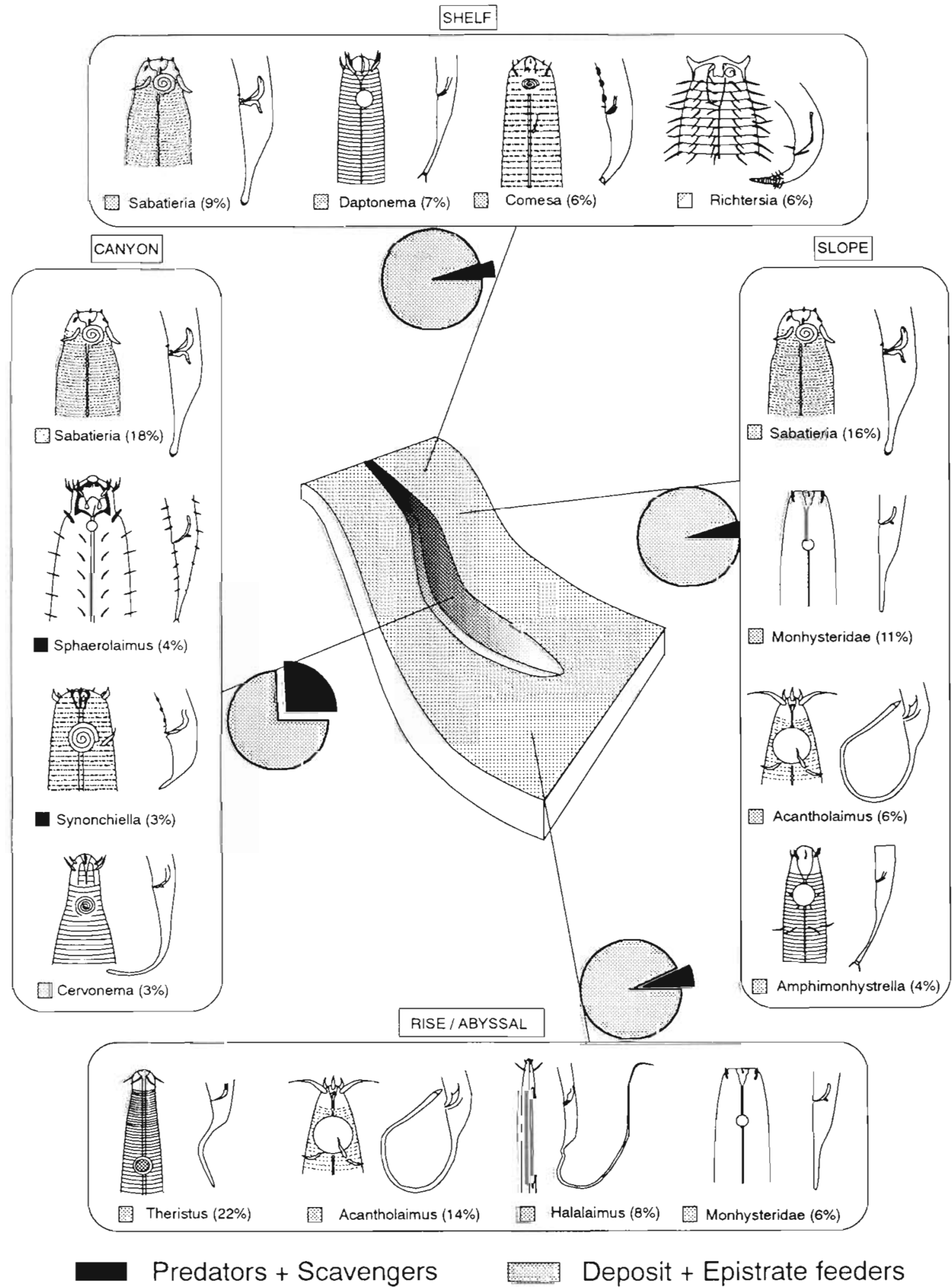

Fig. 7. Graphical representation of the 4 most abundant genera in shelf break, slope, canyon and rise/abyssal sediments. Indicated between brackets is the mean \% abundance; pie diagrams reflect feeding strategies. Note that there were only 3 stations located on the shelf in this study 
derived from the continent (e.g. by means of the river Rhône) (Monaco et al. 1990). Hence relatively large amounts of organic matter settle in these environments and the organic carbon is much more labile compared to deeper sites (Buscail et al. 1990). This increased and high quality food supply could allow for a higher trophic complexity to develop within the nematode community. The distribution of feeding types has been correlated with changes in sediment composition (Tietjen 1971, 1984), but for the Mediterranean canyon, the predominance of predatory and scavenging nematodes does not seem to relate to sediment granulometry (Fig, 6).

Food availability is also enhanced at the HEBBLE site, at the base of the Scotian Rise (Thistle et al. 1985), but the environment here is hydrodynamically very unstable and benthic storms occur frequently. The macrobenthos was shown to be more abundant here (Thistle et al. 1985) while the meiobenthic copepod communities had relatively more burrowing individuals compared to other more undisturbed deep-sea sites (Thistle 1983). Yet the nematode communities were not conspicuously different (Thistle \& Sherman 1985, this study), which seems to suggest that nematodes are unable to profit from enrichment in such physically structured environments.

Although the strong resemblance in generic composition among widely spaced deep-sea sites has been noted before (Thistle \& Sherman 1985, Vincx et al. 1994), this is the first study to consistently compare different areas from the shelf break to hadal depths. We have reiterated the fact that the deep areas are characterized by a complex of the genera Theristus, Acantholaimus + Spiliphera and Halalaimus, but we have also shown that the transition towards this deep-sea assemblage occurs gradually along the ocean margin. The question remains why these genera are so dominant in the deep sea. In fact, the transition from shallow towards the typical deep-sea fauna occurs through the gradual dissappearance of shallow-water nematodes, of which the genus Sabatieria is the most prominent representative (Fig. 8a). Hence an equally relevant question is why this genus, which is so abundant in shallow regions, is not equally dominant in the deeper sites? Many members of the genus Sabatieria are typically found in muddy sediments which are anoxic a few millimeters below the surface (Vanreusel 1990. Vincx et al. 1990, Soetaert et al. in press b). When present in more oxygenated bottoms, they frequently accur deeper down, in the vicinity of the redox-potential-discontinuity layer (Jensen 1983). Along the Mediterranean slope, members of the genus Sabatieria penetrated relatively deep into the sediment (Soetaert et al. in press a), and the same was observed in some stations in the Norwegian Sea (Jensen 1988, Jensen et al. 1992). All this points to a preference for suboxic (or anoxic) environments and it can be assumed that these nematodes will be dominant only in those environments where a substantial fraction of organic matter becomes incorporated below the oxic zone of the sediment. Based on literature data from the Pacific and the Atlantic, we have calculated the amount of mineraliz. able carbon that is not oxidized by oxygen and plotted this against depth (Fig. $8 \mathrm{c}$ ). All estimates were based on nutrient pore-water modelling, as nutrient profiles are sensitive indicators of organic matter mineralization (Jahnke et al. 1982). Although these data are based on other regions than used in the nematode studies, it is clear that the importance of the oxic mineralization pathway increases substantially with depth along the ocean margin. This is caused both by the decreasing flux of organic matter with water depth and the decreasing bioturbation activity ( $K$. Soetaert, P. M. J. Herman \& J. J. Middelburg unpubl.). At great depths nearly all carbon is respired in the oxic zone and oxygen penetrates deep into the sediment; the
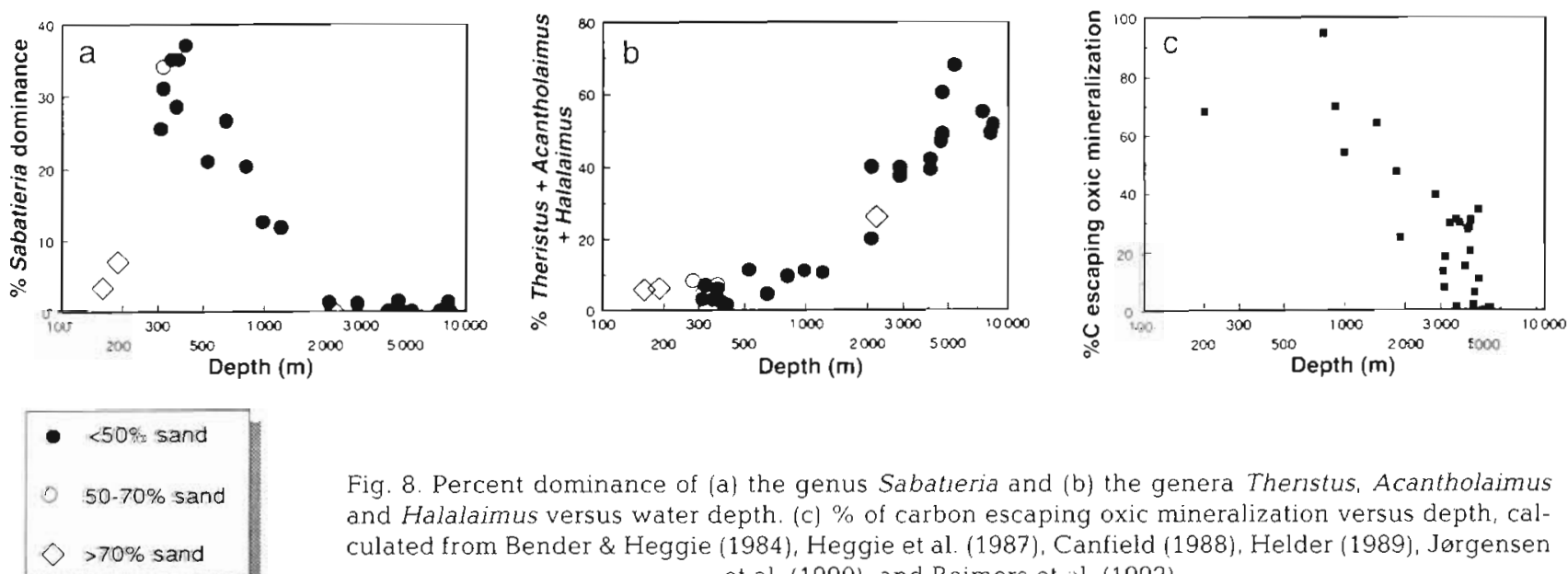

Fig. 8. Percent dominance of (a) the genus Sabatieria and (b) the genera Theristus, Acantholaimus and Halalaimus versus water depth. (c) \% of carbon escaping oxic mineralization versus depth, calculated from Bender \& Heggie (1984), Heggie et al. (1987), Canfield (1988), Helder (1989), Jørgensen et al. (1990), and Reimers et al. (1992) 
small amount of organic matter that reaches the suboxic or anoxic zone (if it exists at all) is much older and more refractory than the carbon that settles on the deep-sea floor (Soetaert et al. unpubl.), hence a nematode community typically associated with these microenvironments cannot develop.

\section{Nematode biomass and density}

Deep-sea meiobenthic animals depend on surfacederived material for their nutrition. The availability of food has important implications for both the standing crop (biomass) of the deep-sea fauna and for the body size of the individuals (Shirayama 1984, Tietjen et al. 1989, Gage \& Tyler 1991). Several variables have been used as indicators of the amount of food that is available to the benthos, e.g. the organic content or chloroplastic content of sediments (Pfannkuche 1985, deBovée et al. 1990, Soetaert et al. 1991a, Vincx et al. 1994), but these parameters tell little about the availability or supply rate of organic matter to the benthos (Tietjen et al. 1989, Rowe et al. 1991). The sedimentary organic carbon content at sampling sites included in this study is very variable, even among neighbouring sites (e.g. the Bay of Biscay), and there is no relationship with either nematode density, mean weight or total biomass.

Organic matter fluxes measured with sediment traps are the best indicators of food input to the benthos that are as yet available for the sites under study, although sediment traps may either over- or underestimate real fluxes (Gardner \& Richardson 1992, Michaels et al. 1994). Tietjen et al. (1989) observed a highly significant relationship between organic flux rates (trap measurements) and total meiobenthic biomass at 4 stations. In this study, nematode biomass increased with increasing flux $\left(\mathrm{r}^{2}=0.89\right.$; Fig. 9a), but this relationship was mainly due to the high values in the Mediterranean canyon, which contributed nearly all of the variance (Fig. 9a). In the Hatteras Abyssal Plain, the high meiobenthic stock was due to the presence of large meiobenthic harpacticoids (Tietjen et al. 1989) and this explains why nematode biomass was so low at this station (compared to the proposed regression). Mean individual nematode weight increased with increasing flux $\left(\mathrm{r}^{2}=0.95\right.$; Fig. 9b), but whereas the relationship between meiobenthos or nematode biomass and organic flux was a linear one (Tietjen et al. 1989, this study), mean individual nematode weight seemed to respond logarithmically to increased organic input.

The flux of organic matter to the bottom depends upon the surface primary production and, because the organic matter degrades while sinking, upon water
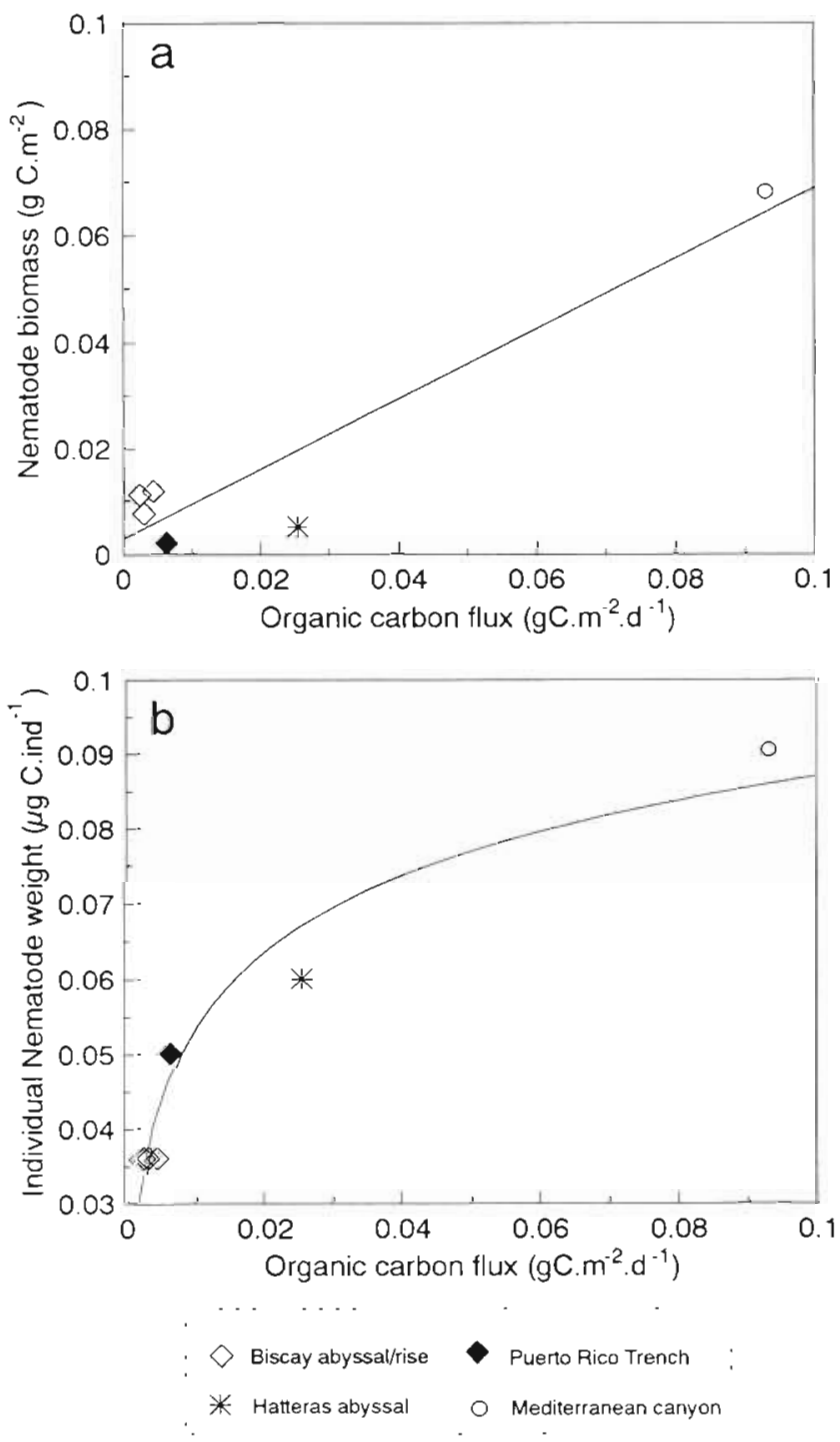

Fig. 9. (a) Nematode biomass and (b) mean nematode carbon weight versus organic flux. The line indicates the best regression

depth (Suess 1980) and temperature (Thiel 1983). Although lateral transport by currents, increased fluxes by migrations of organisms and other processes may interfere with the sinking rate of the debris, water depth is frequently used as an indication of carbon flux (which is convenient as this parameter is always measured). Nematode biomass tended to decrease with depth (Fig. 2) suggesting that food influences the biomass of nematodes as a group. In the Mediterranean, nematode biomass was higher in canyors than in the adjacent deep-sea sites (deBovée et al. 1990, Soetaert et al. 1991a, this study) a phenomenon which was observed for megafaunal animals as well (Sardà et al. 1994) and related to higher organic input in canyons. The oligotrophic nature of 
the Mediterranean basin (Cruzado 1985) and the high temperature of overlying waters $\left(>13^{\circ} \mathrm{C}\right)$, which increases the degradation of the sinking carbon and the maintenance cost of the nematodes (deBovée \& Labat 1993), can then further explain why nematode biomass on the Mediterranean shelf break and slope is so much lower than at stations with comparable depth ranges in the Bay of Biscay.

In conclusion, there exists a natural gradient of nematode community composition from the shelf break up to the greatest depths. In all these environments, the trophic structure of the nematode communities is simple, and nematodes probably compete for the same, bacterial-based food source. When the supply of organic matter to the bottom is high, as in the Mediterranean canyons, a size-based food chain can develop within the nematode communities and predatory nematodes can become an important part of the food web.

Acknowledgements. This manuscript was prepared as part of the Ocean Margin EXchange (OMEX) project, financed by the MAST programme of the Commission of the European Communities (MAS-CT93-0069). The data used in this manuscript were implemented in the commercially available package PARADOX (O Borland). The database (not the package) is available upon request to the authors. This is article number 2010 of the NIOO-CEMO. Drs P. Herman and M. Vincx are acknowledged for critically reading the manuscript.

\section{LITERATURE CITED}

Auffret GA (1985) Environnement morphologique et sédimentologique. In: Laubier $L$, Monniot $C$ (eds) Peuplements profonds du golfe de Gascogne. IFREMER, Brest, $p$ $71-99$

Bender ML, Heggie DT (1984) Fate of organic carbon reaching the deep sea floor: a status report. Geochim cosmochim Acta 48:977-986

Bett B, Vanreusel A, Vincx M, Soltwedel T, Pfannkuche $O$, Lambshead PJD, Gooday AJ, Ferrero T, Dinet A (1994) Sampler bias in the quantitative study of deep-sea meiobenthos. Mar Ecol Prog Ser 104:197-203

Buscail R, Pocklington R, Daumas R, Guidi L (1990) Fluxes and budget of organic matter in the benthic boundary layer over the northwestern Mediterranean margin. Cont Shelf Res 10:1089-1122

Canfield DE (1988) Sulfate reduction and the diagenesis of iron in anoxic marine sediments. PhD dissertation, Yale University, New Haven

Cruzado A (1985) Chemistry of Mediterranean waters. In: Margalev $R$ (ed) Western Mediterranean. Pergamon Press, Oxford, p 126-147

Cruzado A, Velasquez ZR (1990) Nutrients and phytoplankton in the Gulf of Lions, northwestern Mediterranean. Cont Shelf Res 10:931-942

deBovée F, Guidi LD, Soyer J (1990) Quantitative distribution of deep-sea meiobenthos in the northwestern Mediterranean (Gulf of Lions). Cont Shelf Res 10:1123-1145

deBovée F, Labat JP (1993) A simulation model of a deep meiobenthic compartment: a preliminary approach. PSZN I: Mar Ecol 14:159-173

Dinet $A$, Desbruyères $D$, Khripounoff A (1.985) Abondance des peuplements macro et méiobenthiques: répartition et stratégie d'échantillonnage. In: Laubier L, Monniot C (eds) Peuplements profonds du golfe de Gascogne. IFREMER, Brest, p 121-142

Dinet $A$, Vivier MH (1977) Le méiobenthos abyssal du golfe de Gascogne. I. Considérations sur les données quantitatives. Cah Biol mar 18:85-9?

Dinet A, Vivier MH (1979) Le méiobenthos abyssal du golfe de Gascogne. II. Les peuplements de nématodes et leur diversité spécifique. Cah Biol mar 20:109-123

Gage GJ, Tyler PA (1991) Deep-sea biology: a natural history of organisms at the deep-sea floor. Cambridge University press, Cambridge

Gardner WD, Richardson MJ (1992) Particle export and resuspension fluxes in the western North Atlantic. In: Rowe GT, Pariente $V$ (eds) Deep-sea food chains and the global carbon cycle. Kluwer Academic Publishers, Dordrecht, p $339-364$

Gerlach SA, Schrage M, Riemann F (1979) Die Gattung Acantholaimus (Nematoda, Chromadoridae) und Beobachtungen über einen mutmaßlichen Transportmechanismus für Spermien bei $A$. calathus sp. n. Veröff Inst Meeresforsch Bremerhaven 18:35-67

Heggie DT, Marais C, Hudson A, Dymond J, Beach R, Cullen $J$ (1987) Organic carbon oxidation and preservation in NW Atlantic continental margin sediments. In: Weaver PPE, Thomson J (eds) Geology and geochemistry of abyssal plains. Geol Soc Spec Publ ed 31, Geological Society, London, $p$ 215-236

Helder W (1989) Early diagenesis and sediment-water exchange in the Savu Basin (Eastern Indonesia). Neth J Sea Res 24:555-572

Hill MO (1979a) TWINSPAN - a Fortran program for arranging multivariate data in an ordered two-way table by clas sification of the individuals and the attributes. Ecology and systematics. Cornell University, Ithaca

Hill MO (1979b) DECORANA - a Fortran program for detrended correspondence analysis and reciprocal averaging. Ecology and systematics. Cornell University, Ithaca

Isaacs JD, Schwartzlose RA (1975) Active animals of the deep-sea floor. Scient Am 233:84-91

Jahnke R, Emerson S, Murray JW (1982) A model of oxygen reduction, denitrification and organic matter mineralization in marine sediments. Limnol Oceanogr 27:610-623

Jensen $P$ (1983) Meiofaunal abundance and vertical zonation in a sublittoral soft bottom, with a test of the Haps corer. Mar Biol 74:319-326

Jensen P (1987) Feeding ecology of free-living aquatic nematodes. Mar Ecol Prog Ser 35:187-196

Jensen P (1988) Nematode assemblages in the deep-sea benthos of the Norwegian Sea. Deep Sea Res 35:1173-1184.

Jensen P, Rumohr J, Graf G (1992) Sedimentological and biological differences across a deep-sea ridge exposed to advection and accumulation of fine-grained particles. Oceanol Acta 15:287-296

Jørgensen BB, Bang M, Blackburn TH (1990) Anaerobic mineralization in marine sediments from the Baltic Sea-North Sea transition. Mar Ecol Prog Ser 59:39-54

Khripounoff A, Crassous P, Desbruyères D, Le Coz Jr (1985) Le flux organique particulaire et ses transformations à l'interface eau-sédiment. In: Laubier L, Monniot C (eds) Peuplements profonds du golfe de Gascogne. IFREMER, Brest, p 101-118

Michaels AF, Bates NR, Buesseler KO, Carlson CA, Knap AH 
(1994) Carbon-cycle imbalances in the Sargasso Sea. Nature 372:537-540

Monaco A, Courp T. Heussner S, Carbonne J, Fowler SW Deniaux B (1990) Seasonality and composition of particulate fluxes during ECOMARGE-I, western Gulf of Lions. Cont Shelf Res 10:959-987

Pfannkuche $O$ (1985) The deep-sea meiofauna of the Porcupine Seabight and abyssal plain (NE Atlantic): population structure, distribution, standing stocks. Oceanol Acta 8 : $343-353$

Reimers CE, Jahnke RA, McCorkle DC (1992) Carbon fluxes and burial rates over the continental slope and rise of central California with implications for the global carbon cycle. Global biogeochem Cycles 6:199-224

Renaud-Mornant J, Gourbault N (1990) Evaluation of abyssal meiobenthos in the eastern central Pacific (Clarion-Clipperton fracture zone). Prog Oceanogr 24:317-329

Riemann F, Schrage M (1978) The mucus-trap hypothesis on feeding of aquatic nematodes and implications for biodegradation and sediment texture. Oecologia 34:75-88

Rowe G, Sibuet $M$, Deming J, Khripounoff A, Tietjen J, Macko S, Theroux R (1991) 'Total' sediment biomass and preliminary estimates of organic carbon residence time in deep-sea benthos. Mar Ecol Prog Ser 79:99-114

Rutgers van der Loeff MM, Lavaleye MSS (1986) Sediments, fauna and the dispersal of radionuclides at the N.E. Atlantic dumpsite for low-level radioactive waste. Report of the Dutch DORA program. NIOZ, Texel

Sardà F, Cartes JE, Company JB (1994) Spatio-temporal variations in megabenthos abundance in three different habitats of the Catalan deep-sea (Western Mediterranean). Mar Biol 120:211-219

Shirayama Y (1984) The abundance of deep sea meiobenthos in the Western Pacific in relation to environmental factors Oceanol Acta 7:113-121

Soetaert K (1989) The genus Desmoscolex (Nematoda, Desmoscolecidae) from a deep-sea transect off Calvi (Corsica, Mediterranean). Hydrobiologia 185:127-143

Soetaert K, Decraemer W (1989) Eight new Tricoma species (Nematoda, Desmoscolecidae) from a deep sea transect off Calvi (Corsica, Mediterranean). Hydrobiologia 183: $223-247$

Soetaert K, Heip C (1989) The size structure of nematode assemblages along a Mediterranean deep-sea transect. Deep Sea Res 36:93-102

Soetaert K, Heip C, Vincx M (1991a) The meiobenthos along a Mediterranean deep-sea transect off Calvi (Corsica) and in an adjacent Canyon. PSZN I: Mar Ecol 12:227-242

Soetaert K, Heip C, Vincx M (1991b) Diversity of nematode assemblages along a Mediterranean deep-sea transect Mar Ecol Prog Ser 75:275-282

Soetaert K, Vincx M. Heip C (in press a) Nematode community structure along a Mediterranean shelf-slope gradient. PSZN I: Mar Ecol

Soetaert $K$, Vincx $M$, Wittoeck J, Tulkens $M$ (in press b) Meiobenthic distribution and nematode community structure in five European estuaries. Hydrobiologia

Suess E (1980) Particulate organic carbon flux in the oceans - surface productivity and oxygen utilization. Nature 288:260-263

Thiel $H$ (1972) Meiofauna und Struktur der benthischen Lebensgemeinschaft des Iberischen Tiefseebeckens. 'Meteor' Forschungsergeb Reihe D 12:36-51

Thiel $\mathrm{H}(1975)$ The size structure of the deep-sea benthos. Int Rev ges Hydrobiol 60:575-606

Thiel H (1983) Meiobenthos and nanobenthos of the deep sea.
In: Rowe GT (ed) The sea, Vol 8. John Wiley \& Sons, Inc, New York, p 167-229

Thiel H, Pfannkuche O, Schriever G, Lochte K, Gooday AJ, Hemleben Ch, Mãntoura RFG. Turley CM, Patching JW, Riemann F (1988/1989) Phytodetritus on the deep-sea floor in a central oceanic region of the northeast Atlantic. Biol Oceanogr 6:203-239

Thistle D (1983) The stability-time hypothesis as a predictor of diversity in deep-sea soft-bottom communities. Deep Sea Res 30:267-277

Thistle D, Sherman KM (1985) The nematode fauna of a deepsea site exposed to strong near-bottom currents. Deep Sea Res 9:1077-1088

Thistle D, Yingst JY, Fauchald K (1985) A deep-sea benthic community exposed to strong near-bottom currents on the Scotian Rise (Western Atlantic). Mar Geol 66:91-112

Tietjen JH (1971) Ecology and distribution of deep-sea meiobenthos off North Carolina. Deep Sea Res 18: 941-957

Tietjen JH (1976) Distribution and species diversity of deepsea nematodes off North Carolina. Deep Sea Res 23: $755-768$

Tietjen JH (1984) Distribution and species diversity of deepsea nematodes in the Venezuela Basin. Deep Sea Res 31: 119-132

Tietjen JH (1989) Ecology of deep-sea nematodes from the Puerto Rico Trench area and Hatteras Abyssal Plain. Deep Sea Res 10:1579-1594

Tietjen JH (1992) Abundance and biomass of metazoan meiobenthos in the deep sea. In: Rowe GT, Pariente $V$ (eds) Deep sea food chains and the global carbon cycle. Kluwer Academic Publishers, Dordrecht, p 45-62

Tietjen JH, Deming JW, Rowe GT, Macko S, Wilke RJ (1989) Meiobenthos of the Hatteras Abyssal Plain and Puerto Rico Trench: abundance, biomass and associations with bacteria and particulate fluxes. Deep Sea Res 36: $1567-1577$

Vanreusel A (1990) Ecology of the free-living marine nematodes from the Voordelta (Southern Bight of the North Seaj. I. Species composition and structure of the nematode communities. Cah Biol mar 31:439-462

Vanreusel A, Vincx M, Van Gansbeke D, Gijselinck W (1992) Structural analysis of the meiobenthos communities of the shelf break area in two stations of the Gulf of Biscay (NE Atlanticl. Belg J Zool 122:185-202

Vincx M, Bett BJ, Dinet A, Ferrero T, Gooday AJ, Lambshead PJD, Pfannkuche O, Soltwedel T, Vanreusel A (1994) Meiobenthos of the deep Northeast Atlantic: a review. Adv mar Biol 30:1-88

Vincx M, Meire P, Heip C (1990) The distribution of nematode communities in the southern bight of the North Sea. Cah Biol mar 31:107-129

Vitiello P (1976) Peuplements de nématodes marins des fonds envasés de Provence. II. Fonds détritiques envasés et vases bathyales. In: Annales de l'Institut Océanographique, Vol 52. Masson, Paris, p 283-311

Vivier MH (1978) Influence d'un déversement industriel profond sur la nématofaune (canyon de Cassidaigne. Méditerranée). Téthys 8:307-321

Vivier MH (1985) Espèces du genre Acantholaimus (Nematoda, Chromadoridae, Spilipherinae). In: Laubier L, Monniot $C$ (eds) Peuplements profonds du golfe de Gascogne. IFREMER, Brest, p 331-349

Wieser W (1953) Beziehungen zwischen Mundhöhlengestalt, Ernährungsweise und Vorkommen bei freilebenden marinen Nematoden. Ark Zool 2(4):439-484 